Accessed on: http://jkb.ub.ac.id/index.php/jkb/article/view/2650

Jurnal Kedokteran Brawijaya Vol. 31, No. 1, Februari 2020, pp. 33-38

Article History: Received 23 October 2019, Accepted 29 November 2019

$\underline{\text { Research Article }}$

\title{
Correlation between Ultrasound Findings of Uric Acid Precipitate in MTP I and Acute Gout Flare in Gouty Arthritis
}

\section{Hubungan antara Temuan Presipitat Kristal Monosodium Urat pada MTP I Menggunakan Ultrasound dengan Terjadinya Serangan Akut pada Penderita Artritis Gout}

\author{
Elys Susanti ${ }^{1}$, Muhammad llyas ${ }^{2}$, Nurlaily Idris ${ }^{3}$, Andi Alfian Z, Bachtiar Murtala ${ }^{5}$, Faridin HP \\ ${ }^{1}$ Radiology Department Faculty of Medicine Universitas Hasanuddin Makassar \\ ${ }^{4}$ Public Health Sciences Department Faculty of Medicine Universitas Hasanuddin Makassar \\ ${ }^{6}$ Internal medicine Department Faculty of Medicine Universitas Hasanuddin Makassar
}

\begin{abstract}
Acute gout flare is the most common manifestation of gouty arthritis that intermittently occurs with severe pain in the joints due to interactions between monosodium urate crystals (MSU) and the surrounding tissues. The most common predilection is the metatarsophalangeal joint (the $1^{\text {st }} \mathrm{MTP}$ ). Ultrasound examination is a modality that can be used to visualize MSU crystal precipitates in and around joints. This study aimed to determine the correlation between the findings of the MSU crystal precipitate on the $1^{\text {st }}$ MTP using ultrasound with the occurrence of acute gout flare in gout patients. This study was an analytical observational study with a cross-sectional method. The samples were 41 patients with a history of previous acute flares and in the intercritical phase when participating in the study. Examinations of ultrasound on the $1^{\text {st }}$ MTP and random serum uric acid level were performed. Evaluations were carried out on both of the $1^{\text {st }}$ MTPs to assess the shape of the MSU crystalline precipitate, namely Double Contour Sign (DCS), aggregate, and tophus. Each sample was evaluated within five days to assess the presence or absence of an acute flare. The diagnostic tests used were the ChiSquare Test and the Fischer Exact Test with a significance value of $p<0.05$. The results showed the images of DCS were seen in 20 samples with 9 (45\%) samples experiencing acute flare ( $p<0.05)$, while in 21 samples where no DCS were found, all did not experience any flare. Findings of aggregate and tophus were rarely found, $7.3 \%$ and $4.9 \%$, respectively. In this study, the finding of DCS precipitates using ultrasound has a significant correlation to the emergence of acute flare and is a significant form of precipitate findings in this study, whereas aggregate and tophus precipitates are difficult to determine.
\end{abstract}

Keywords: Acute gout flare, gout, MSU crystals, ultrasound

\begin{abstract}
ABSTRAK
Serangan akut merupakan manifestasi tersering dari artritis gout yang terjadi karena interaksi antara kristal monosodium urat (MSU) dan jaringan sekitarnya yang bersifat intermitten dengan gambaran nyeri hebat pada persendian. Predileksi tersering yaitu pada sendi metatarsophalangeal (MTP I). Pemeriksaan ultrasonografi merupakan modalitas yang dapat digunakan untuk memvisualisasi presipitat kristal MSU pada dan sekitar persendian. Penelitian ini bertujuan untuk mengetahui hubungan antara temuan presipitat kristal MSU pada MTP I menggunakan USG dengan terjadinya serangan akut pada pasien gout. Penelitian ini merupakan penelitian analitik observasional dengan metode cross-sectional. Sampel berjumlah 41 dengan riwayat serangan akut sebelumnya dan berada pada fase interkritikal saat memasuki penelitian. Dilakukan pemeriksaan USG pada MTP I dan pemeriksaan kadar asam urat serum sewaktu. Evaluasi dilakukan pada kedua MTP I untuk menilai bentuk presipitat kristal MSU: Double Contour Sign (DCS), agregat, dan tophus. Setiap sampel dievaluasi dalam rentang waktu 5 hari untuk dinilai ada tidaknya serangan akut. Uji diagnostik menggunakan uji ChiSquare dan Uji Fischer Exact Test dengan nilai signifikansi $p<0,05$. Hasil penelitian memperlihatkan gambaran DCS terlihat pada 20 sampel dengan 9 (45\%) sampel mengalami serangan akut $(p<0,05)$, sedangkan pada 21 sampel yang tidak ditemukan DCS, seluruhnya tidak mengalami serangan. Temuan gambaran agregat dan tophus jarang ditemukan, masingmasing $(7,3 \%)$ dan $(4,9 \%)$. Pada penelitian ini didapatkan temuan presipitat DCS menggunakan USG mempunyai hubungan yang signifikan terhadap munculnya serangan akut dan merupakan bentuk temuan presipitat yang bermakna dalam penelitian ini, sedangkan pesipitat agregat dan tophus sulit ditentukan.
\end{abstract}

Kata Kunci: Serangan akut, gout, kristal MSU, ultrasound

Correspondence: Elys Susanti. Radiology Department Faculty of Medicine Universitas Hasanuddin Makassar, Jl. Perintis Kemerdekaan KM. 11, Tamalanrea Indah, Kec. Tamalanrea, Kota Makassar, Sulawesi Selatan 90245 Tel. 085255552680 Email: luvlizt@gmail.com

DOI: http://dx.doi.org/10.21776/ub.jkb.2020.031.01.7 


\section{INTRODUCTION}

Gout is one of the most common types of inflammatory arthritis, which occurs as a result of monosodium urate crystal formation triggered by hyperuricemia (1). Globally, the incidence of gout has increased and has been linked to several conditions, such as changes in dietary patterns, lifestyles, drug use, and age. Gout is three to four times more common among men than women, and the incidence in women increases after menopause and after reaching the age of 60 (2). In Indonesia, there are not many epidemiological publications about gouty arthritis (3).

Gout occurs due to metabolic disorders and inflammation. The pathogenesis of gout is because two processes occur simultaneously, namely (1) excessive uric acid formation at a level that causes the formation of uric acid crystalline precipitates and (2) inflammatory response that occurs due to the presence of uric acid crystals (4). Clinical manifestations of gout refer to interactions between MSU crystals and the surrounding tissue. Clinical manifestations of gout consist of four stages, namely asymptomatic hyperuricemia, acute gout arthritis, intercritical or gout intervals, and chronic gout arthritis $(5,6)$.

Acute gouty arthritis is the most common manifestation of this disease, which is characterized by a typical flare that is intermittent and accompanied by a condition that gives a very severe feeling of pain in the joints. In this phase, there are many signs as an inflammatory response to the presence of MSU crystals, in the form of severe pain, touch/pressure pain, sudden onset, and accompanied by swelling with or without erythema that reaches a peak within a few hours with most frequent initial manifestations in the joint metatarsophalangeal (the $1^{\text {st }}$ MTP). This acute flare can recur and, in patients who are not treated properly, will eventually cause chronic arthritis and deformity in the joints (5-7).

The phase between flares is called the intercritical phase. Patients who are often in this period can be diagnosed through ACR (American College Rheumatology) criteria. One criterion of the 2015 ACR is the appearance of MSU crystal deposits on the articular surface which gives an image of DCS $(6,8,9)$.

Postulate from one of the studies mentioned that after the uric acid crystals disappeared from the joints, the acute flare of gout did not recur until the condition where hyperuricemia triggered the formation of uric acid crystals in the joints appeared again $(8,10)$.

In 2012, OMERACT (Outcome Measures in Rheumatology) held an international meeting at the ACR congress. In this meeting, three series were carried out in determining and validating basic lesions related to gouty arthritis in the ultrasound examination, and a conclusion and determination of basic lesions related to gout by ultrasound examination were made, namely DCS, aggregates, erosion, and tofus (11).

Musculoskeletal ultrasound is an imaging modality that has huge benefits. This equipment is not invasive, safe, easily accessible, and technically easy to apply to patients, affordable, and without specific contraindications. Crystal material can manifest in joints or soft tissue, which provides waves that are stronger than the surrounding tissue so it will be easier to detect. Ultrasound can be used as a tool to diagnose and monitor the therapeutic progress of early manifestations of this disease (12).
There were several studies using ultrasound in detecting lesions associated with gouty arthritis, including research conducted by Das S, et al. that mentioned the ability of musculoskeletal ultrasound (MSUS) in diagnosing gout in the intercritical and chronic phases of the $1^{\text {st }}$ MTP in the form of a Double Contour Sign and a tophy (13). Other researchers also mentioned the ability of ultrasound that could help to identify images of MSU crystal deposits in the joints that even have no symptoms (14). Likewise, a study conducted by Zhu L, et al. in China stated that DCS and aggregate images had high sensitivity in detecting gouty arthritis (15).

Although there have been several previous studies conducted by other researchers related to the ability of ultrasound in detecting lesions related to gouty arthritis, the study related to the ability of ultrasound in detecting MSU crystal precipitates that was used as one of the modalities to assess occurrence of acute flare had never been carried out, so the researchers were interested in doing this research. The hypothesis of this study was that there was a correlation between the findings of gout crystal precipitate (MSU) using ultrasound with the occurrence of acute gout flare in gouty arthritis patients. This study aimed to determine the correlation between the findings of the MSU crystal precipitate on the $1^{\text {st }}$ MTP using ultrasound with the occurrence of acute gout flare in gouty arthritis patients.

\section{METHODS}

\section{Study Design}

This study was an analytical observational study with a crosssectional design conducted at the Radiology Department of the Central General Hospital Dr. Wahidin Sudirohusodo Makassar from June to August 2019. Variables in this study consisted of independent variables that were random uric acid levels in $\mathrm{mg} / \mathrm{dl}$ and images of MSU crystal precipitates using ultrasound (DCS, aggregate, and tophus images) with objective criteria of found or not found. The dependent variables were acute flare of gouty arthritis assessed based on clinical criteria of symptomatic episodes, which consisted of pain that develops <24 hours, pain due to touch or pressure, erythema and difficulty in walking or cannot use the joints involved, especially on the $1^{\text {st }}$ MTP. It is said to have an acute gout flare if at least one criterion appears.

The target population in this study were all patients diagnosed with gout arthritis based on the ACR/EULAR criteria. The accessible population in this study were all patients with gouty arthritis, those who came to the radiology department of Wahidin Sudirohusodo Hospital and those referred from the rheumatology polyclinic and were diagnosed by a rheumatologist. The sample in this study were all accessible populations that met the research criteria. The inclusion criteria in this study were men $>40$ years old, women $>60$ years old or were menopause, and patients diagnosed with intercritical gouty arthritis (with a history of previous acute flare). Exclusion criteria in this study were gout arthritis patients with a history of trauma on the $1^{\text {st }}$ MTP, patients with tumors (malignant or nonmalignant), patients with obesity (Body Mass Index (BMI) $\geq 30$ ), and those who were unwilling to participate in the study.

\section{Data Collection Methods}

This study received ethical approval from the Health Research Ethics Committee of RSUP Dr. Wahidin Sudirohusodo Makassar, Number 537/UN4.6.4.5.31/ 


\section{Pp36/2019}

Patients with a diagnosis of intercritical stage gout arthritis who met the inclusion criteria were included in the study. Administrative data were recorded, and patients' identities that meet the inclusion criteria were registered by providing a full explanation, and they would fill out and sign an informed consent paper if agreed. The patient underwent musculoskeletal ultrasound examination in the supine position with knees bent and plantar pedis resting on a flat plane. The probe (6-15 MHZ frequency linear transducer) was placed on the $1^{\text {st }}$ MTP in a perpendicular direction to the joint surface, in a longitudinal and transverse position. Dorsal, medial, and plantar aspects were evaluated and then assessed for the presence or absence of lesions.

The reading of the ultrasound results was carried out by researchers with guidance from one of the consultants in the field of musculoskeletal. Based on the results of the ultrasound examination, patients were grouped into two groups, that were patients with the discovery of uric acid crystal precipitates (DCS and/or aggregates, and/or tophi) in the joints, and groups without the discovery of precipitates on the $1^{\text {st }}$ MTP. Both groups were observed within 5 days and evaluated whether or not the patient had repeated arthritis flare or not, under criteria of a flare which were pain that develops $<24$ hours, pain due to touch or pressure, erythema and difficulty in walking or cannot use the joints involved, especially on the $1^{\text {st }}$ MTP. It is said to have an acute gout flare if at least one criterion arises. Every patient who had undergone a musculoskeletal ultrasound examination on the $1^{\text {st }}$ MTP would be asked to check their random uric acid levels in Wahidin Sudirohusodo Hospital laboratory. The results of the examination were recorded in a research format and then analyzed.

\section{Data Analysis Technique}

Data were processed using the $22^{\text {nd }}$ version of the SPSS (Statistical Software Program Social Science) software with the Chi-Square statistical test and the Fischer's Exact Test. The results of the study were presented in tabular forms.

\section{RESULTS}

The sample in this study was as many as 41 people. Images of MSU crystal precipitates were found in either one or both the $1^{\text {st }}$ MTP in 21 samples, while in the other 20 samples, there were no findings of the MSU crystal precipitates on both of the $1^{\text {st }}$ MTP using ultrasound. Figure 1 shows the findings of the MSU crystalline precipitates, either DCS, aggregate, or tophus on the $1^{\text {st }}$ MTP.

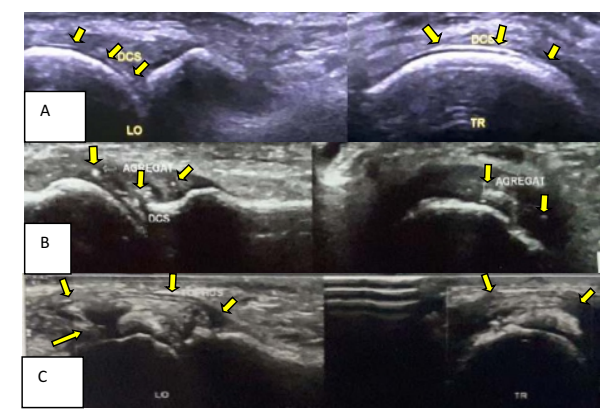

Figure 1. Example image of an MSU crystal precipitate using ultrasound on the $1^{\text {st }}$ MTP
Note: The results of the ultrasound examination on the $1^{\text {st }}$ MTP with an image of the MSU crystal precipitate. All studies were performed in longitudinal and trans/axial views. A). Intermitten hyperechoic band (DCS precipitate) (arrows) was seen overlying the anechoic hyaline cartilage of the metatarsal head, B). Intraarticular distribution of hyperechoic foci (aggregate precipitate) (arrows) and C). Inhomogeneous material surrounded by a small anechoic rim (tophus precipitate) (arrows) around the $1^{\text {st }}$ MTP joint.

Based on the demographic data in Table 1, the highest number of samples was within the age range of 51-60 years, as many as 18 samples or $43.9 \%$ while the smallest number was in the age range of $71-80$ years and $81-90$ years as many as $1 \%$ and $2.4 \%$, respectively. The frequency and percentage of samples by gender showed that the highest number of samples was in males as many as 28 of samples or $68.3 \%$, while in females was as many as 13 samples or $31.7 \%$.

Table 1. Distribution of sample characteristics by demographics

\begin{tabular}{llrr}
\hline Variables & Group & $\mathbf{f}(\mathbf{n}=\mathbf{4 1})$ & \multicolumn{1}{c}{$\%$} \\
\hline Age & $40-50$ yo & 9 & 22 \\
& $51-60$ yo & 18 & 43.9 \\
& $61-70$ yo & 12 & 29.3 \\
& $71-80$ yo & 1 & 2.4 \\
Gender & $81-90$ yo & 1 & 2.4 \\
& Male & 28 & 68.3. \\
& Female & 13 & 31.7. \\
\hline
\end{tabular}

Source: Primary Data, f: frequency, $n=$ Amount, \%: percentage

Table 2, the distribution of samples based on the examination results of uric acid levels showed that samples with normal level of uric acid were 24 samples or $58.5 \%$, and the distribution of samples with hyperuricemia were 17 samples or $41.5 \%$. Based on the results of the ultrasound examination, the uric acid crystal precipitates in the form of DCS images were found 20 samples or $48.8 \%$, and no precipitates in the form of DCS were found in 21 samples or $51.2 \%$. The images of the uric acid crystal precipitate in the form of aggregate were found in 3 sample or 7.3\%; there was no images of aggregate precipitate found in 38 samples or $92.7 \%$. The images of uric acid crystalline precipitates in the form of tophus were found in 2 samples or $4.9 \%$, and in 39 samples or $95.1 \%$, tophus precipitate was not found. Table 2 showed the distribution of research samples based on the presence or absence of acute flare of gout arthritis, which was found in as many as 9 or $22.0 \%$ of the samples experienced acute flare, and 32 samples or $78.0 \%$ did not experience acute flare.

Table 2. Distribution of sample characteristics based on serum uric acid levels, ultrasound findings of uric acid type and acute gout flare

\begin{tabular}{llrc}
\hline \multicolumn{1}{c}{ Variables } & \multicolumn{1}{c}{ Group } & $\mathbf{f ~ ( n = 4 1 )}$ & $\%$ \\
\hline Uric acid levels & Hyperuricemia & 17 & 41.5 \\
& Normal & 24 & 58.5 \\
Precipitate: & & & \\
-DCS & Found & 20 & 48.8 \\
& Not found & 21 & 51.2 \\
-Aggregate & Found & 3 & 7.3 \\
& Not found & 38 & 92.7 \\
\hline
\end{tabular}


Table 2. Distribution of sample characteristics based on serum uric acid levels, ultrasound findings of uric acid type and acute gout flare (Continued)

\begin{tabular}{llrr}
\hline \multicolumn{1}{c}{ Variables } & \multicolumn{1}{c}{ Group } & $\mathbf{f}(\mathbf{n = 4 1 )}$ & \multicolumn{1}{c}{$\%$} \\
\hline -Tophus & Found & 2 & 4.9 \\
& Not found & 39 & 95.1 \\
-Acute gout flare & Found & 9 & 22 \\
& Not found & 32 & 78 \\
\hline
\end{tabular}

Source: Primary Data, f: frequency, $n=$ Amount, \%: percentage

The results of the Chi-Square test analysis showed a significant correlation between uric acid levels with the findings of the DCS precipitates using ultrasound, the value Prevalence Odd's Ratio (POR) $=7.893$, and $\mathrm{Cl}=1.898-32.817$. It can be seen in the table, the images of the DCS precipitates found in as many as $13(76.5 \%)$ samples under hyperuricemia conditions and $7(29.2 \%)$ samples at normal uric acid levels. Based on aggregate findings using ultrasound, the aggregate images were not found on most samples, as many as 38 samples, and the aggregate images were found only in 3 samples. In samples where aggregates were not found, only about 7 samples (18.3\%) experienced acute gout flare, and 31 (81.6\%) samples did not experience acute flare. From 3 samples found in aggregate, $2(66.7 \%)$ experienced flare and $1(33.3 \%)$ sample did not experience acute gout flare. This showed that there was no significant difference in the distribution of acute gout flare in groups that had aggregates and those who did not have aggregates based on ultrasound ( $p>0.05)$.

From the Table 3, it can be seen that the samples with an aggregate finding have 8,857 times odds with $95 \% \mathrm{Cl} 0.7$ 111.9 to experience an acute flare compared with samples that do not have the aggregate images based on the results of an ultrasound examination. Based on the findings of tophus using ultrasound, it is obtained that in most samples (39 samples) tophus images were not found, and the tophus images were found only in 2 samples. In samples that tophus were not found, about 8 $(20.5 \%)$ samples experienced an acute flare, and $31(79.5 \%)$ samples did not experience an acute flare. While from 2 samples where tophus were found, 1(50\%) experienced a flare and the other (50\%) samples did not experience a flare. This showed that there was no significant difference in the distribution of acute flare in the group who had tophus and in the group who did not have tophus based on ultrasound. From the table, it could be seen that samples with tophus findings have 3,875 times odds with $95 \% \mathrm{Cl}$ 0.2-68.9 to experience an acute flare compared to samples where tophus were not found, based on the results of an ultrasound examination.

Table 3. Relationship of variables according to uric acid levels to the images of DCS precipitates, aggregate precipitates to acute gout flare, tophus precipitate to acute gout flare

\begin{tabular}{lrrrrrrr}
\hline & \multicolumn{2}{c}{ DCS } & & & & \\
\cline { 2 - 3 } & & Found & $\begin{array}{c}\text { Not } \\
\text { Found }\end{array}$ & $\mathbf{n}$ & $\mathbf{P}$ & POR & \\
\hline $\begin{array}{l}\text { Uric Acid Status } \\
\text { Hyperuricemia }\end{array}$ & 13 & 4 & & 0,008 & 7.893 & $1.898-32.817$ \\
Normal & 7 & 17 & & & & \\
\hline
\end{tabular}

Table 3. Relationship of variables according to uric acid levels to the images of DCS precipitates, aggregate precipitates to acute gout flare, tophus precipitate to acute gout flare

\begin{tabular}{|c|c|c|c|c|c|c|}
\hline & \multicolumn{2}{|c|}{ DCS } & \multirow[b]{2}{*}{$\mathrm{n}$} & \multirow[b]{2}{*}{$\mathbf{P}$} & \multirow[b]{2}{*}{ POR } & \multirow[b]{2}{*}{$\mathrm{Cl}$} \\
\hline & Found & $\begin{array}{l}\text { Not } \\
\text { Found }\end{array}$ & & & & \\
\hline & \multicolumn{2}{|c|}{ Acute Flare } & & & & \\
\hline \multicolumn{7}{|l|}{$\begin{array}{l}\text { Aggregate } \\
\text { Precipitates }\end{array}$} \\
\hline Found & 2 & 1 & 3 & & & \\
\hline Not Found & 7 & 31 & 38 & 0.116 & 8.857 & 0.701-111.937 \\
\hline \multicolumn{7}{|l|}{ Tophus } \\
\hline \multicolumn{7}{|l|}{ Precipitates } \\
\hline Found & 1 & 1 & 2 & 0395 & 3875 & 04218-68942 \\
\hline Not Found & 8 & 31 & 39 & ל כ & & $0.210-00.742$ \\
\hline
\end{tabular}

Source: Primary Data. Chi-Square test. POR: Prevalence Odds Ratio, $\mathrm{Cl}$ : Confidence Interval

The aggregate images were only found in hyperuricemia conditions, as many as $3(17.6 \%)$ samples, while the aggregate images were not found in all samples with normal uric acid levels, which were 24 (100\%) samples. There was no significant difference in the distribution of aggregate images in hyperuricemia and normal groups $(p>0.05)$. The tophus images found in $2(11.8 \%)$ samples in hyperuricemia conditions and not found in 15 (88.2\%) samples that also have hyperuricemia. While tophus images were not found in samples with normal uric acid level, which were 24 (100\%) samples. The Fischer Exact Test results found that $p=0.166$. This shows that there was no significant difference in the distribution of tophus images in the hyperuricemia and normal groups ( $p>0.05)$. Of the 20 samples that had DCS precipitates, acute gout flare occurred in 9 (45\%) samples, and of the 21 samples that did not have a precipitate image, none had experienced flare. Based on the Chi-Square test results, it is obtained that the DCS precipitate images have a significant relation with $p$-value $<0.001$.

Table 4. Relationship of variables according to uric acid levels to the images of aggregate precipitate, tophus precipitate, and DCS precipitate for acute gout flare

\begin{tabular}{|c|c|c|c|c|}
\hline & Found & Not Found & $\mathbf{n}$ & $\mathbf{P}$ \\
\hline \multicolumn{5}{|l|}{ Uric Acid Status: } \\
\hline \multicolumn{5}{|l|}{ Aggregate } \\
\hline Hyperuricemia & 3 & 14 & & \multirow{2}{*}{0.064} \\
\hline Normal & 0 & 24 & & \\
\hline \multicolumn{5}{|l|}{ Tophus } \\
\hline Hyperuricemia & 2 & 15 & & \multirow{2}{*}{0.166} \\
\hline \multirow[t]{2}{*}{ Normal } & 0 & 24 & & \\
\hline & \multicolumn{2}{|c|}{ Acute flare } & & \\
\hline \multicolumn{5}{|l|}{ DCS precipitates } \\
\hline Found & 9 & 11 & 20 & $<0.001$ \\
\hline Not Found & 0 & 21 & 21 & \\
\hline
\end{tabular}

Source: Primary Data. Fisher Exact Test, $n$ : Amount. Chi-Square Test

\section{DISCUSSION}

Frequency and sample presentation based on age showed the highest number in the age range of 51-60 years, which were 18 samples or $43.9 \%$ while the least amount was in the age range of 71-80 years and $81-90$ years as many as 1 
sample each or $2.4 \%$. The youngest person in the study sample was 45 years old male, while the oldest was 81 years. Furthermore, the highest frequency and percentage by gender were in males, as many as 28 samples or $68.3 \%$, while in females, there were 13 samples or $31.7 \%$. Based on the distribution of demographic data (gender and age) from this study, the number of men (68.3\%) was higher compared to women. The distribution of samples in women was that 8 (61.5\%) samples were under the age of 60 but have experienced menopause, and as many as $5(38.5 \%)$ samples were above 60 . This is in line with research put forward by Saigal $R$ who stated that gout was three to four times more common in men than women and the incidence in women increased after menopause and after reaching 60 years old (2).

In this study, it is found that uric acid had a significant meaning on precipitate findings by using ultrasound in the form of DCS, which was found in hyperuricemia conditions as many as 13 samples (76.5\%) while in 7 samples (29.2\%) normal uric acid levels were found. This can be explained and in line with research conducted by Thiele who stated that the image of DCS would disappear if uric acid was maintained at the level of $\leq 6 \mathrm{mg} / \mathrm{dl}$ and the loss of DCS would take about 8-18 months after uric acid levels were maintained below normal values (16). However, in this study, no information was available related to uric acid levels and ultrasound imaging of the $1^{\text {st }}$ MTP prior to the beginning of the study, so it was not known whether the existing DCS image was a new form of crystalline precipitate or a precipitated crystal deposit that had formed before.

Based on uric acid levels on aggregate ultrasound images, it was found that in hyperuricemia conditions, three samples or (17.6\%) had aggregate images, and in normouricemic conditions, no aggregate images were found in the whole sample. In this regard, literature that discusses the correlation between uric acid levels with aggregate images on ultrasound has not yet been available, but this could be explained through research conducted by Zhu Liang et al. who conducted a study on DCS images and hyperechoic aggregates using ultrasound and found that there were differences in the proportions of the findings of the DCS and aggregate images, namely the DCS images were more commonly found in the lower extremities while the aggregates were more common in the upper extremities. This difference in distribution could be caused by the activeness of the joints in movement which could trigger the movement of uric acid crystals to be deposited on the surface of the cartilages or deposited in the surrounding tissue as tophus. Although statistically not significant $(P>0.05)$, when seen in the normouricemic group in this study, no aggregate image was found in the whole sample (16).

The influence of uric acid levels on tophus in this study was as many as $2(4.9 \%)$ samples under hyperuricemia conditions and were not found in normouricemic conditions. This was explained in a study conducted by Zhang Qingyu et al. who stated that normally, the formation of tophi proceeded slowly and only if the duration of the disease had progressed for 12.5 years (17). However, in this study no data was collected related to the duration of the sample who experienced the disease. Although statistically not significant $(P>0.05)$, when compared with the normouricemic group, overall no image of tophi was found in the $1^{\text {st }}$ MTP.

In this study, the effect of DCS findings on the emergence of acute gout flare was found in $9(45 \%)$ samples in subjects found with DCS images and no flare were found in $21(100 \%)$ samples in group without DCS images. Statistically, the results of this study were significant. Based on the findings of ultrasound examination in the form of an aggregate, it was found as many as $3(7.3 \%)$ samples from the whole sample, and of the three samples, 2(66.7\%) samples experienced an acute flare. However, the result was not statistically significant. Similarly, in the sample with tophus findings based on ultrasound, it was found as many as $2(4.8 \%)$ samples from the whole sample and $1(50 \%)$ sample from both samples were found to have an acute flare. However, based on statistical analysis between the findings using ultrasound in the form of tophus, it was not significantly meaningful to the emergence of acute flare. This could be explained in research conducted by Fernando Perez-Ruiz, who explained that once formed, MSU crystals could cause acute, self-limited, inflammatory flares, probably triggered by crystal shedding from the cartilago surface into the joit space, where they could interact with resident cells. Therefore, gout had to be viewed as a chronic, progressive disease if serum uric acid levels were not appropriately lowered. By lowering serum uric acid levels at least below $6 \mathrm{mg} / \mathrm{dl}$, dissolution of the pathogenic MSU crystals was achieved and disappearance of clinical features of gout could be obtained (9). In another research by Fernando Perez-Ruiz, explained that in patients who received gout-lowering therapy, uric acid crystals would float in joint fluid, and if the gout-lowering therapy was not given antiinflammatory therapy, it would usually be able to bring out the risk for recurring acute flare. It is also mentioned that aggregates were faster to dissolve than DCS, and DCS would be faster to dissolve than crystalline deposits in tophus form. The main purpose of reducing uric acid levels was to dissolve the uric acid crystals so that the risk of inflammation decreased, and only if the uric acid level rose again then new crystals would form again, and this had a risk for emergence of recurrent acute flare (11). In this study, there was no information related to the ultrasound imaging of the $1^{\text {st }}$ MTP prior to the start of the study, so it was not known whether the present DCS, aggregate, or tophus images were the newly formed crystalline precipitates or were old precipitated crystals, and it was also unknown whether during this research, the subjects followed the rules for not taking antiinflammatory drugs.

It can be concluded from this study that the findings of monosodium urate crystalline precipitates in the form of double contour sign found by ultrasound examination has a significant correlation to the emergence of acute flare in gouty arthritis patients and is a form of precipitates which is meaningful in this study, whereas aggregate and tophus precipitates are difficult to determine. The most common monosodium urate crystal precipitates found on ultrasound examination in this study were double contour sign images (48.8\%), whereas aggregate and tophus images were less common, as many as (7.3\%) and $(4.9 \%)$ respectively. 


\section{REFERENCES}

1. Li Q, Li X, Kwong JSW, et al. Diagnosis and Treatment for Hyperuricaemia and Gout: A Protocol for a Systemic Review of Clinical Practice Guidelines an Consensus Statements. British Medical Journal Open. 2017; 7(6): 1-6.

2. Saigal R and Agrawal A. Pathogenesis and Clinical Management of Gouty Arthtritis. The Journal of the Association of Physicians of India. 2015; 63(12): 5663.

3. Widyanto FW. Artritis Gout dan Perkembangannya. Saintika Medika. 2014; 10(2): 145-152.

4. Keenan RT, Nowatzky J, and Pillinger M. Etiology and Pathogenesis of Hyperuricemia and Gout. In: Ruddy S, Sergent J, Harris T, et al (Eds). Kelley'sTextbook of Rheumatology Ninth Edition. Philadelphia: Elsevier. 2011: 1554-1565.

5. Busso $\mathrm{N}$ and So A. Mechanisms of Inflammation in Gout. Arthritis Research \& Therapy. 2010; 12(2): 206.

6. Neogi T, Jansen TL, Dalbet N, et al. 2015 Gout Classification Criteria. Arthritis \& Rheumatology. 2015; 67(10): 2557-2568.

7. Ragab G, Elshahaly M, and Bardin T. Gout: A Old Disease in New Perspective-A Review. Journal of Advanced Research. 2017; 8(5): 495-511.

8. Perez-Ruiz F, Dalbeth N, and Bardin T. A Review of Uric Acid, Crystal Deposition Disease, and Gout. Advances in Therapy. 2015; 32(1): 31-41.

9. Stewart S, Dalbeth N, Vandal A, Allen B, Miranda R, and Rome K. Ultrasound Features of the First Metatarsophalangeal Joint in Gout and Asymptomatic Hyperuricaemia: Comparison with Normouricaemia Individuals. Arthritis Care \& Research. 2017; 69(6): 875-883.
10. Perez-Ruiz F. Treating to Target: A Strategy to Cure Gout. Rheumatology. 2009; 48: ii9-ii14.

11. Gutierrez M, Schmidt W, Thiele R, et al. International Consensus for Ultrasound Lesions in Gout: Results of Delphi Process and Web-Reliability Exercise. Rheumatology. 2015; 54(10): 1797-1805.

12. Scirocco Chiarra, Rutigliano IM, Finucci A, and lagnocco A. Musculoskeletal Ultrasonography in Gout. Medical Ultrasonography. 2015; 17(4): 535540.

13. Das S, Ghosh A, Ghosh P, Lahiri D, Sinhamahapatra P, and Basu K. Sensitivity and Specificity of Ultrasonographic Fatures of Gout in Intercritical and Chronic Phase. International Journal of Rheumatology Diseases. 2017: 20(7): 887-893.

14. Ogdie A, Taylor WJ, Neogi T, et al. Performance of Ultrasound in the Diagnosis of Gout in a MultiCenter Study: Comparison with Monosodium Urate Crystal Analysis as the Gold Standard. Arthritis \& Rheumatology. 2017; 69(2): 429-438.

15. Thiele RG and Schlesinger N. Ultrasonography Shows Disappearance of Monosodium Urate Crystal Deposition on Hyaline Cartilage after Sustained Normouricemia is Achieved. Rheumatology International. 2010; 30(4): 495-503.

16. Zhu L, Zheng S, Wang W, Zhou Q, and Wu H. Combining Hyperechoic Aggregates and the Double Contour Sign Increases the Sensitivity of Sonography for Detection of Monosodium Urate Deposits in Gout. Journal of Ultrasound in Medicine. 2017; 36(5): 935940.

17. Zhang Q, Gao F, Sun W, Ma J, Cheng L, and Li Z. The Diagnostic Performance of Musculoskeletal Ultrasound in Gout: A Systemic Review and Metaanalysis. PLoS One. 2018; 13(7): 1-14. 